* Corresponding author Phone +421556022450 E-mail address:miroslav.pastor@tuke.sk (Ing. Miroslav Pástor, PhD.)

Article information Article history: AMS-Volume16-No.3-00152-12 Received 14 January 2012 Accepted 25 February 2012

\section{Methodology for Experimental Verification of Safety of Packages for Transport of Spent Nuclear Fuel}

\author{
František Trebuňa*, František Šimčák, Peter Trebuňa, Zdenko Bobovský, Miroslav \\ Pástor, Patrik Šarga, Peter Frankovský, Martin Hagara
}

Department of Applied Mechanics and Mechatronics, Faculty of Mechanical Engineering, Letná 9, 04200 Košice, Slovak Republic

\section{BIOGRAPHICAL NOTES}

Dr.h.c. mult. prof. Ing. František Trebuňa, CSc. is a professor of applied mechanics, Head of the Department of Applied Mechanics and Mechatronics and Dean of the Faculty of Mechanical Engineering. He is author of 10 monographs, 12 university textbook, special book publications, 12 university notebooks and more than 300 publications in journals and conference proceedings at Slovakia abroad. He is author of important projects and engineering works. He received several prizes at home and abroad. He received three titles Doctor Honoris Causa (DHC) including two from foreign universities for the development of applied mechanics and mechatronics.

prof. Ing. František Šimčák, CSc. he is a professor of applied mechanics, Deputy head of the Department of Applied Mechanics and Mechatronics. He is author of 4 monographs, 7 university textbooks, 6 university notebooks and more than 200 publications in journals and conference proceedings at Slovakia and abroad. He received several prizes due to his scientific results.

doc. Ing. Peter Trebuňa, PhD. He si assoc. prof. On Department of Industrial engineering and management. In the year 2007 he recieved PhD. In the field of business mangament. In the year 2010 he work out his habilitation thesis and became assoc. prof. He works on scientific and research projects on the department and publishes the results in journals and conference proceedings at Slovakia and abroad. He made remarkable work on the building of laboratories of his department and on publication of monographs and university textbook at the department.

Ing. Zdenko Bobovský, PhD. is an assistant of the Department of Applied Mechanics and Mechatronics at Faculty of Mechanical Engineering at Technical University of Košice. He received B.Sc. degree in production systems with industrial robots and manipulators (2002), M.Sc degree in Construction of robotics system (2005), M.Sc degree in automotive production (2007), Medal of Dean for excellent student (2007) and Ph.D in Production system at the same faculty (2009). His current fields of interest are mechatronics, metamorphous self-reconfigurable modular robotic systems and applied mechanics. Ing. Miroslav Pástor, PhD. He is a senior assistant on the Department of Applied Mechanics and Mechatronics. In 2008 he received PhD. in the field of applied mechanics. He works on scientific and research projects on the department and publishes the results. He made remarkable work on the building of laboratories and on publication of monographs and university textbook at the department.Ing. Patrik Šarga, PhD. He graduated in "Automation and Control in Mechanical Engineering" at Technical University of Košice in 2002. He was an internal PhD. student at the Department of Applied Mechanics and Mechatronics and in 2005 he defended his dissertation thesis in field of mechatronics. Nowadays he works as an assistant on the Department of Applied Mechanics and Me- 
chatronics at the Faculty of Mechanical Engineering at Technical University of Košice. He is co-author of one book of lecture notes and more than 50 publications in journals and conference proceedings at Slovakia and abroad, e.g. Engineering Failure Analysis, Metalurgija. He has worked on several grant projects, research tasks and many projects solved for industry realized on the department.

Ing. Peter Frankovský, PhD. He is a senior assistant on Department of Applied Mechanics and Mechatronics. In 2010 he received PhD. in the field of applied mechanics. He works on scientific and research projects on the department and publishes the results in journals and conference proceedings at Slovakia and abroad. He made remarkable work on the building of laboratories and on publication of monographs and university textbook at the department.

Ing. Martin Hagara after successful completion of his study at the Gymnasium of Pavol Orszagh Hviezdoslav in Kezmarok he has started studies at the Faculty of Mechanical Engineering of the Technical university of Kosice. He graduated a bachelor-degree study in Mechatronics in 2008. Thereafter he continued an engineer-degree study in Applied Mechanics. He defended his diploma thesis „Application of digital image correlation in solving problems of modal analysis" in 2010. Because of the results he has reached, he has been awarded the medal of excellent student by dean of the Faculty of mechanical engineering of the Technical university of Kosice. Nowadays he is a student of PhD-degree study in Applied mechanics, where he carries out research in methodics of digital image correlation in solving problems of mechanical structures dynamics.

\section{KEY WORDS}

Regulation of nuclear regulatory authority, demands for transportation of radioactive material, procedures for tests of packages, experimental methods of mechanics

\section{ABSTRACT}

Experimental methods of mechanics can be used for verification of lifespan of structures and for assessment their safe operation. For transport of radioactive materials is necessary to use packages that fulfill severe rules declared by laws and regulations. In the paper are given experimental procedures used for verification of safety of packages used for transport of spent nuclear fuel.

\section{Introduction}

Regulation of Nuclear regulatory authority of the Slovak republic No.57/2006 Z.z. declares details to demands for transport of radioactive materials. Supplement No.1 of this regulation gives general demands that must fulfill all packages and transport containers used for this purpose. Procedures for test of packages are given in Supplement No. 4 of above-mentioned regulation. The fulfillment of demands has to be verified by tests on real specimens or models that have similar basic properties as have the verified objects. For the scale-down models, the parameters of the tests have to be adjusted appropriately [Vyhláška č.57/2006 Z.z.].

In the paper is described procedure for experimental verification of safety of package for transfer of used fuel realized on the workplace of authors [Trebuňa et al. 2011a, Trebuňa et al. 2011b, Trebuňa et al. 2011c]. The method of experimental verification has been elaborated on the basis of results of analytical and numerical modeling that was done in the context of international standards [Trebuňa - Šimčák 2005].

On the basis of analytical and numerical computations was developed the following procedure for experimental verification:

a) determination of geometrical deviations of packages from projected values,

b) determination of material decrements as result of abrasion or corrosion,

c) identification of permanent deformations of individual parts of packages,

d) experimental verification of fixtures (for lifting) or their blocking,

e) determination of residual stresses in packages due to overloading, production technology, radiation or thermal influences,

f) identification of loading under operation conditions and conditions defined by regulation.

g) realization of experiments that are connected with prescribed tests (e.g. free fall of container in various positions, penetration tests and so on),

h) providing of experimental modal analysis of packages including transport complex,

i) tests under water.

Experimental verification in parts a) to $f$ ), h) was accomplished on real packages. For the realization of tests in parts $\mathrm{g}$ ) and i) was created 1:8 scale mod- 
el.

\section{Experimental Analysis Realized on Real Con- tainers for Transport of Used Nuclear Fuel}

Object of experimental verification was transport container for spent nuclear fuel according to Fig. 1.

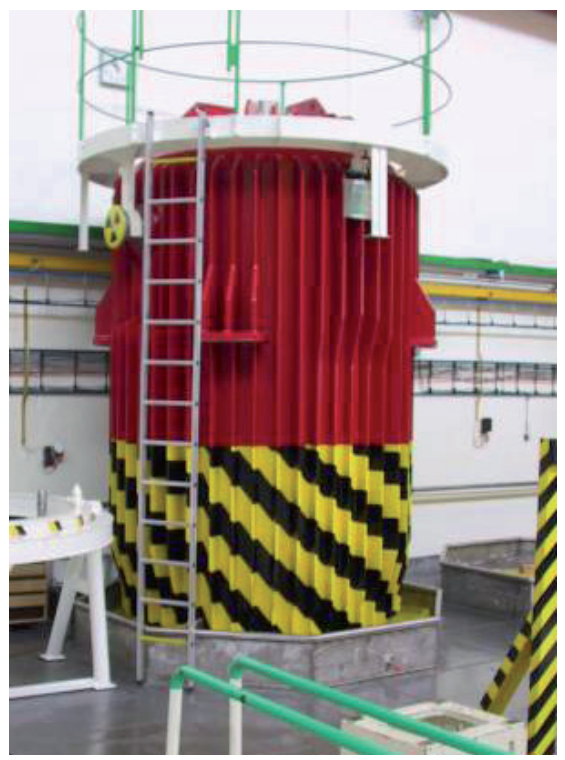

Fig. 1: Transport container for used nuclear fuel

\subsection{Detection of differences on packages with respect to projected values}

Measurement procedure in the literature [Trebuňa et al. 2011a, Trebuňa et al. 2011c].

\subsection{Detection of material decreasing resulting due to} abrasion and corrosion

Measurement of thickness of lid, body and ribs of container in chosen locations (Fig.2) was realized by ultrasound measurement system TG-400 (Fig.3), with precision of measurement $0,01 \mathrm{~mm}$. For the measurement was used direct ultrasound probe NTD SYSTEMS C11 (Fig.4), with frequency $5 \mathrm{MHz}$ and range of measurement from 1,6 mm to 508 $\mathrm{mm}$. In order to ensure acoustic feedback between measured surface and ultrasound probe, ULTRAGEL $\|^{\circledast}$ was used (Fig.3).

\subsection{Identification of permanent deformations of indi-} vidual parts of packages

Local plastic deformations were investigated in the first step by visual control. Plastic deformations can be identified also on the basis of results of measurement of geometric parameters by contactless geodetic methods (chapter 2.1).
In Fig.4 is given example of identification of plastic deformation on the container rib.

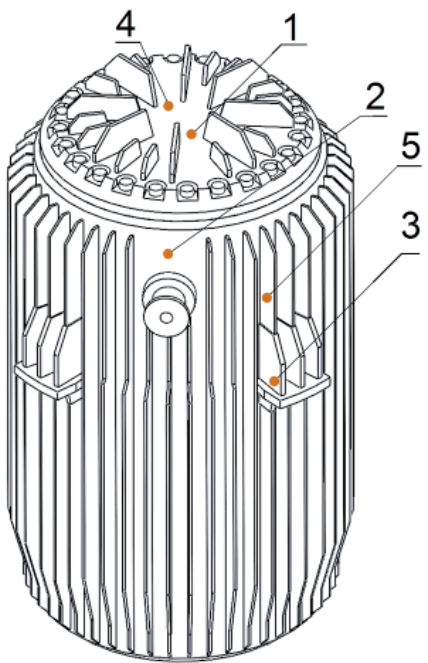

Fig. 2: Labeling of location of thickness measurements.

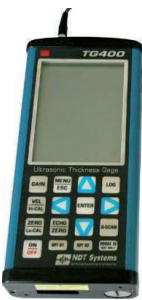

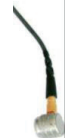

b)

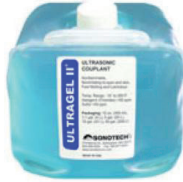

Fig. 3: a) ultrasound apparatus TG-400; b) probe NTD SYSTEMS (11; c) ULTRAGEL II

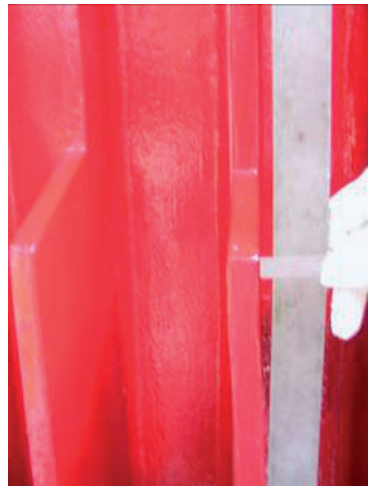

Fig. 4: Plastic deformation of container rib.

\subsection{Experimental verification of container fixture}

In accordance with supplement No. 1 of Regulation No. 57/2006, the lifting pins of container have to withstand all loadings resulting from manipulation with container by prescribed manners. It 
means that fixing equipment and whatever part of container used for lifting have to allow manipulation with container.

Analyzed type of container has four footings that serve for fixation of container to transport means, and two pins serving for manipulation with container. Because, according to the operator, the footings can not be used for lifting, there were experimentally checked only pins of container

The container pins were verified by classical manual computation as well as by using FEM and dynamic loading [Trebuňa - Šimčák 2005]. For the experimental verification of computed values of stresses (including verification of dynamic coefficient, which was assigned to be 1.4 in accordance with tables for lifting machines) the method of strain gage method based on electrical resistance was used. On top sides of container pins were applied strain gage rosettes, (for thermal compensation) in locations 9 and 10, near to the connection of pins to the container body (Fig.5).
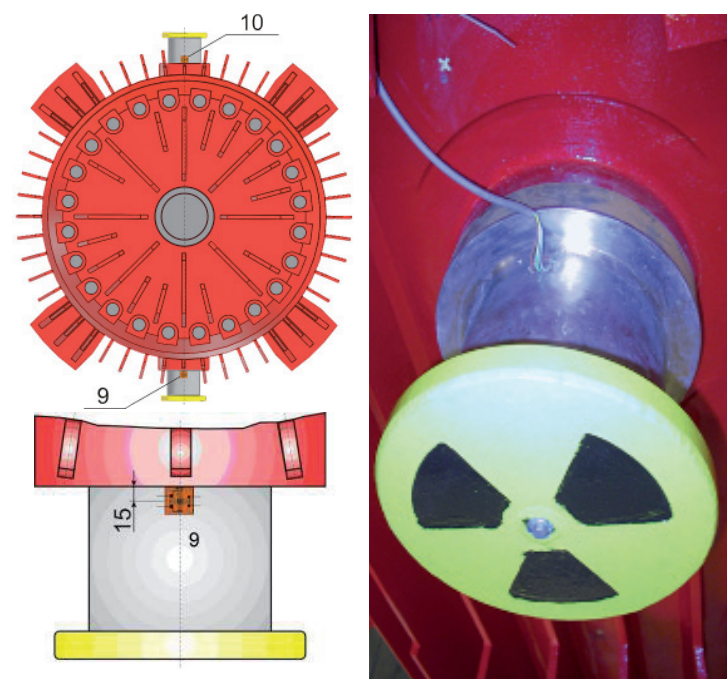

Fig. 5: Location of strain-gages in locations 9 and 10 on the pins of container.

\subsection{Residual stresses in the body of container}

For the measurement of residual stresses was applied strain gage method using drilling of hole [Standard ASTM E 837-01, Trebuňa - Šarga 2011d]. With respect to conditions of drilling, it was necessary to choose strain gages RY 21, which have soldered output from their manufacturing. Equipment RS 200 was used for the drilling of holes. Methodology of hole drilling was in accordance with standard ASTM E 837-01 and TECHNOTE TN 503-6 [Müller et al. 2007, Wille et al. 2007].

In Fig.6 is shown analyzed container as well as position and orientation of strain gages for the hole drilling. Locations of measurement were selected on the basis of results of analytical and numerical methods [Trebuňa - Šimčák 2005]. They include areas of possible overloading during operation or radiation and thermal influences.
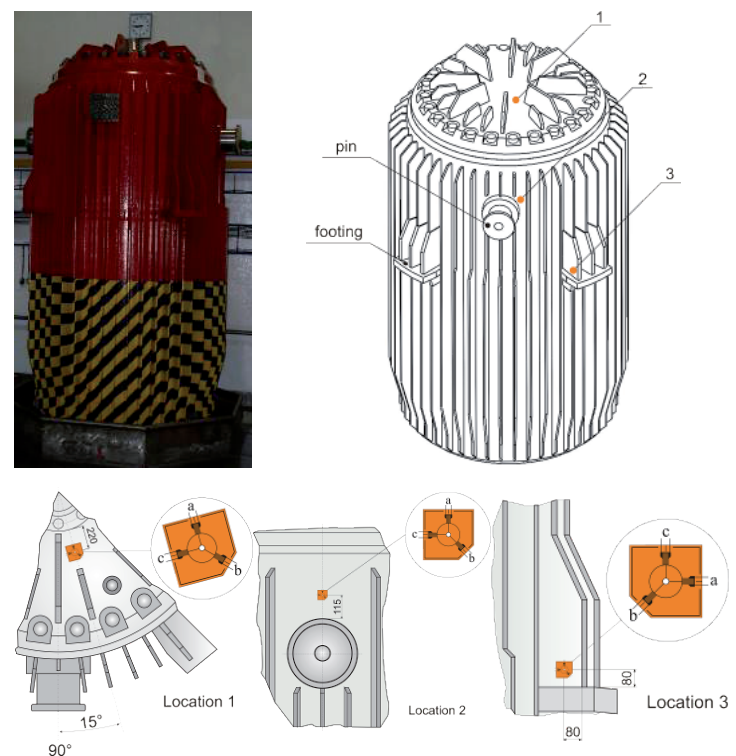

Fig. 6: Analyzed container, localization of strain-gages for the hole-drilling method on the body of container.

\subsection{Identification of loading under operational condi- tions - stress analysis due to thermal influences}

The aim of thermal analysis of container was to show that after filling of container by spent nuclear fuel rods, the heat resulting from radioactive decay is not accumulated under prescribed transport and test conditions and the allowed limit temperatures and stresses are not exceeded in the body of container [Vyhláška č.57/2006 Z.z.].

According to Regulation No.57/2006 Part VIII, outside temperature during using of transport container can lie in interval $-40^{\circ} \mathrm{C}$ to $+38^{\circ} \mathrm{C}$. According to Section 14 Pert VIII, on easy accessible part of surface the temperature can not exceed $85^{\circ} \mathrm{C}$. It is the reason, why for this relatively high temperature the safety parameters have to be determined and these have to be verified by experimental methods. The authors have chosen, with agreement of operator, the test by heating of operation medium 
in container. The procedure of test realization was based on installation of heating coils in cassettes of container.

In order to identify loading due to heating, on the container body were applied 8 strain gages, while four measurement locations (assigned 1 to 4) were on cooling ribs over fixation flanges and four assigned 5 to 8 (in pairs, because of plane stress state) were applied on the lid of container. Location of strain gages on the container body is given in Fig.7.

During heating, the temperatures of water in container, its surface and ambient was measured by contact sensors. Temperature of container surface was scanned during whole measurement by thermovision camera TR1.
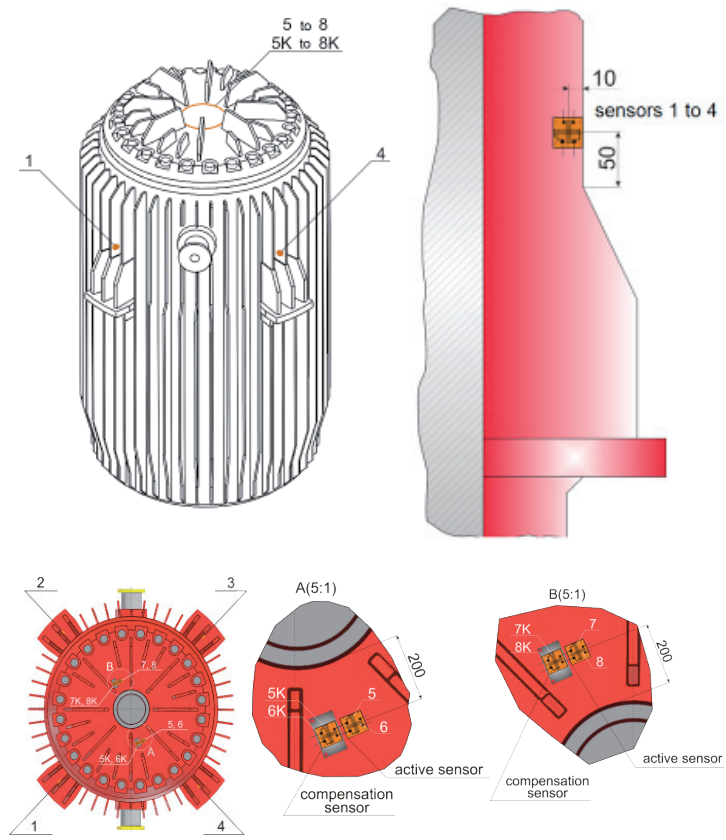

Fig. 7: Localization of strain-gages on the container body.

\subsection{Modal analysis resulting from vibration analysis of the complex during its transport}

According to Supplement No. 1 of Regulation No. 57/2006, Part II., the consignment have to withstand any accelerations, vibrations, or resonances that can arose under conditions presumable during normal transport without decreasing of tightness of closure mechanisms in different parts of package or without violation of its integrity. From this reason has been accomplished modal analysis and analysis of vibration of system container
- wagon, during its movement with prescribed velocity, starting, breaking as well as movement through twists and locations, where mechanical vibration of system could occur [Múller et al. 2007]. Container was positioned during the transport on special railway wagon (Fig. 8).

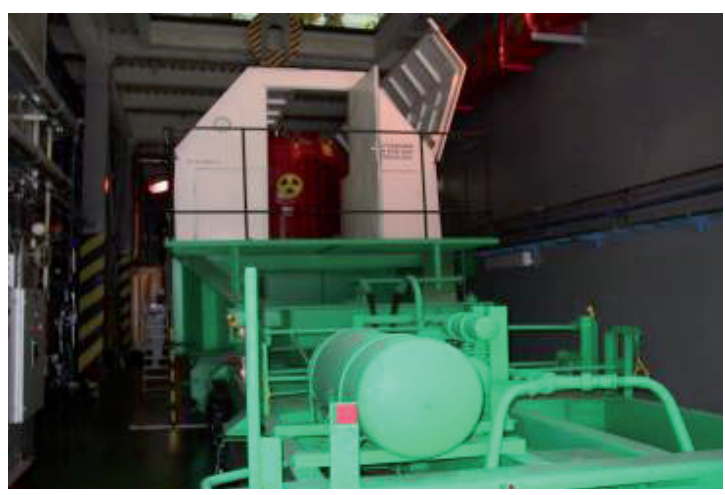

Fig. 8: View to transport complex with container.

Modal analysis of carrying part of wagon bridge was realized for two positions of three-axis acceleration sensor Brüel \& Kjær 4506B. Sensor S1 was positioned on a lid of container (Fig.9 a) and sensor S2 on a frame of undercarriage above pan of wagon bearing (Fig.9 b). Locations of sensors allow gaining information about transmission of vibration excitation during movement of complex.
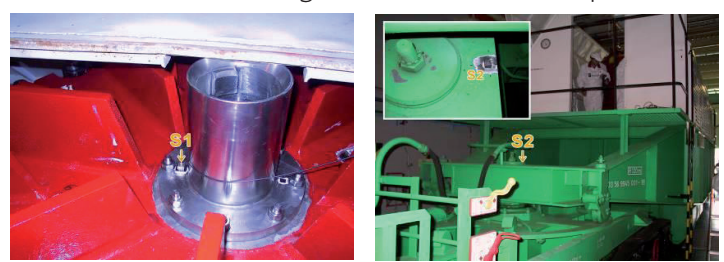

Fig. 9: a) position of sensor 51 on the lid of container, b) position of sensor $\$ 2$ on the frame of carriage over the rotation pin on wagon.

The locations of hammer impact were chosen in such a way that the longitudinal and transversal symmetry of wagon has been exploited. There were chosen 9 locations for excitation by impact hammer. The locations were the same for both sensors (S1 and S2). Acceleration sensors S1 and S2 had axis $x$ in vertical direction, axis y was oriented perpendicular to axis of wagon and axis $z$ was identical with wagon's axis. Functions of frequency transfer measured for individual positions of excitation were processed in program Pulse Reflex. Software algorithms using function CMIF (Complex Mode Indicator Function) has been used for 
estimation of eigenshapes and eigenfrequencies. The eigenfrequencies by this procedure are determined on the basis of analysis of stability diagrams [Trebuňa et al., 2011e].

Measurement of operational vibration of transport complex during its movement was realized on railway road of length approximatelly $3600 \mathrm{~m}$. The road was divided to 5 sections (see Tab.1) with considerably different characteristics of driving. Maximum velocity of complex during measurement was $40 \mathrm{~km} / \mathrm{h}$, which corresponds to value received from operator.

Table 1: Lengths and short description of road sections.

\begin{tabular}{lll} 
Section number & Section length & $\begin{array}{l}\text { Description of } \\
\text { section }\end{array}$ \\
\hline 1 & $800 \mathrm{~m}$ & $\begin{array}{l}\text { Movement from } \\
\text { station - typi- } \\
\text { cally crossing } \\
\text { several railway } \\
\text { switches. } \\
\end{array}$ \\
2 & $400 \mathrm{~m}$ & $\begin{array}{l}\text { Right twist. } \\
\text { Relatively }\end{array}$ \\
3 & $600 \mathrm{~m}$ & $\begin{array}{l}\text { straight road. } \\
\text { Left twist. }\end{array}$ \\
4 & $150 \mathrm{~m}$ & Relatively \\
5 & $1650 \mathrm{~m}$ & straight road.
\end{tabular}

For the measurement of vibration deflections were used three-component acceleration sensors Bruel\&Kjaer 4506B, applied in locations S1 and S2. The sensors were connected to measurement system Bruel\&Kjaer PULSE 3560 that records time-dependent charts of acceleration deflections to the hard disc of notebook.

\section{Experimental analysis realized on the con- tainer model}

The drop tests, penetration tests and tests under water (outer pressure) were accomplished on the 1:8 scale model (Fig. 10).

In accordance with Regulation of Nuclear Regulatory Authority of the Slovak Republic - ÚJD SR No.57/2006, the packages for transport of radioactive materials have to meet requirements declared for normal and accident conditions of transport. During the test, the container is falling onto a target (punch) - whereby the aim is to cause the maximum possible damage. Under normal transport conditions the height of falling, measured from the lowest point of specimen to the upper part of target, cannot be smaller than the distance given in Tab.2 for the given weight of consignment. According to the table, for test with a model with weight smaller than $5000 \mathrm{~kg}$ height of the free fall should be $1.2 \mathrm{~m}$. In case of drop test of real container falling on target the height of the fall should be $0.3 \mathrm{~m}$.
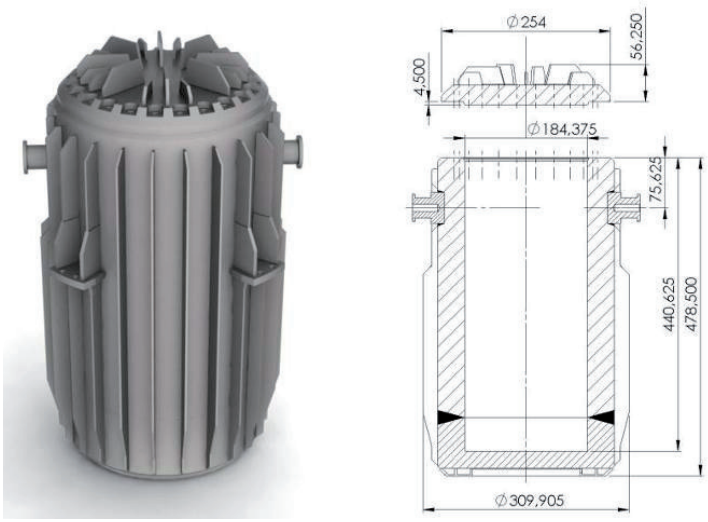

Fig. 10: Model of container for drop tests.

Table 2: Hight of free fall for testing packages under normal transport conditions.

\begin{tabular}{ll}
\hline Weight of package [kg] & Free fall heigh [m] \\
\hline $\begin{array}{ll}\text { Smaller than } 5000 & 1,2 \\
5000 \text { or more, but less } & 0,9 \\
\text { than } 10000 & \\
\begin{array}{l}10000 \text { or more, but less } \\
\text { than } 15000\end{array} & 0,6 \\
\text { more than } 15000 & 0,3\end{array}$
\end{tabular}

Impact effect caused by container drop can be modeled by falling from height $1 \mathrm{~m}$ on a steel punch of prescribed shape and dimensions and fixed perpendicular to the target (penetration test) [Vyhláška č.57/2006 Z.z.]. Drop tests of packages were realized by free fall on test equipments. Drop tests of model were accomplished on test stand (Fig.11) that was designed and manufactured especially for this occasion and allows positioning of model.

The pad (target) for drop tests has to fulfill conditions defined by regulations [Vyhláška č.57/2006 Z.z.,Wille et al. 2007]. The target for the drop test was the steel plate with mass approximately 1700 $\mathrm{kg}$ which was fixed to massive assembling plate. The drop tests should be realized in such position 
of container in which the most serious damage occurs. For the drop tests of model were chosen orientations according to Fig.12.

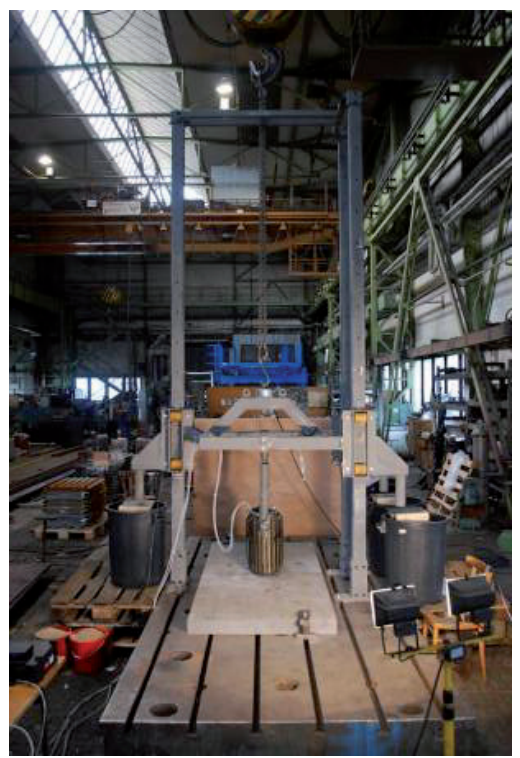

Fig. 11: Test stand for drop tests of model.

During the drop test were applied on the truck of test stand and on the lid of container model acceleration sensors. The strains were measured by strain gages applied on container model.

The penetration test of packages for radioactive material is prescribed by regulation [Vyhláška č.57/2006 Z.z.] and it should demonstrate fact that package is able to withstand accidents during transport (failure conditions).

The opinion with small-scale models of containers shows that analytical assessments and numerical computations considering real values of material properties are comparable with results of experimental measurements [Trebuňa et al., 2011e]. Orientation of model with respect to the punch for individual penetration tests, i.e. positions of model at the moment of impact on a punch were the same as were during drop test but with labels $C 1$ to $C 5$. In order to take into account design of verified containers, the heights of falling do not differ very much from fall height $1 \mathrm{~m}$ for real container. The tests were accomplished on real stand for drop tests (Fig.11) For the penetration test were used acceleration sensors similarly as for drop tests (on the truck of test stand and on the body of container model).

\subsection{Tests by outside pressure}

Test by outer pressure allow to verify using model loading under operation conditions that are defined by Regulation No.57/2006 Z.z. of Nuclear regulatory authority of Slovak republic, that gives details for transport conditions for nuclear materials.

After detailed analysis of results of computer verification of container and extensive consultations with operator the decision was made that due to small stress levels and big stiffness of a lid and due to removing of coating color on the surface, that the strain-gage methods will be used for the measurement on the model of container.

The tests of model should confirm integrity of container as well as its internal volume under predefined operation and failure conditions. Application of strain-gages is seen from figures. The locations were chosen on the basis of computer verification of pressure test (Fig.13).

During the pressure test the container was given into test container filled by water (Fig.14) and pressure to level of $300 \mathrm{kPa}$. During the measurement were measured strains in locations of strain-gages and also the tightness of the connection between lid and body was investigated.

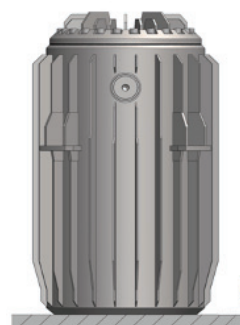

B1

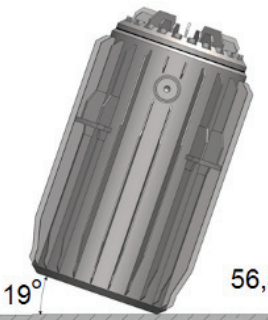

B2

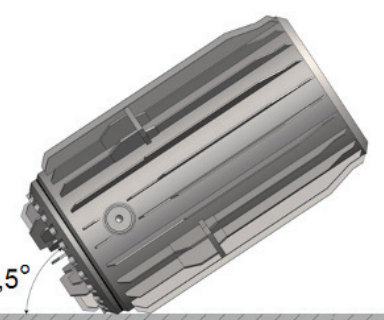

B3

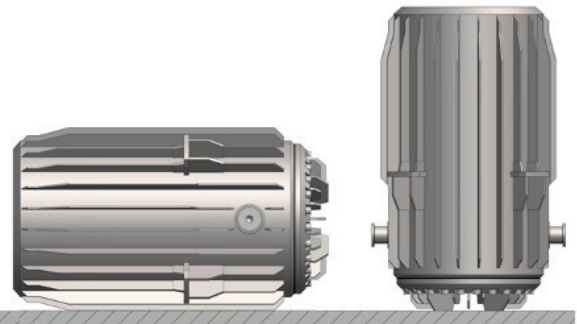

B4

Fig. 12: Orientation of model for drop tests. 

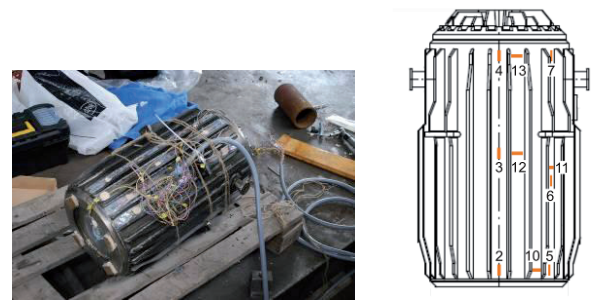

a)
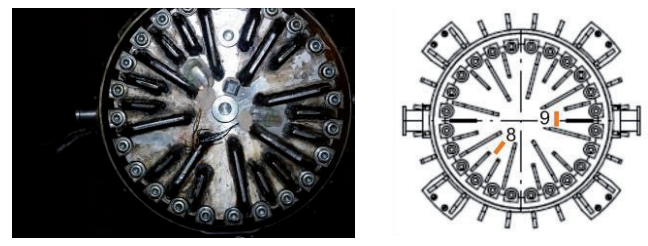

b)
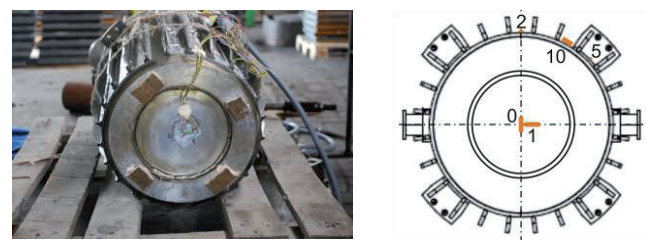

c)

ensure that container undoubtedly fulfills all demands of above-mentioned regulation.

\section{Acknowledge}

The authors would like to express their gratitude to Scientific Grant VEGA MŠ SR for the support of this work under Project No. 1/0289/11 and No. 1/0937/12

\section{References}

[1] Vyhláška č.57/2006, Z.z., UJD SR ktorou sa ustanovujú podrobnosti o požiadavkách pri preprave rádioaktívnych materiálov, zo dňa 12.1.2006.

[2] Trebuňa, F. et al., 2011a: Overenie zostatkovej životnosti transportného kontajnera C-30/002, Košice, máj - august 2011.

[3] Trebuňa, F. et al., 2011b:Typové merania a skúšky transportného kontajnera C-30, Záverečná správa, Košice, máj - september 2011.

[4] Trebuňa, F. et al., 2011c: Overenie zostatkovej životnosti transportného kontajnera C-30/006, Košice, október 2011.

[5] Trebuňa, F., Šimčák, F., 2005: Kvantifikácia zvyškových napätí tenzometrickými metódami. Grafotlač, Prešov.

Fig. 13: Position of sensors for the tests by outside pressure a) on the body, b) on the lid, c) on the bottom part.
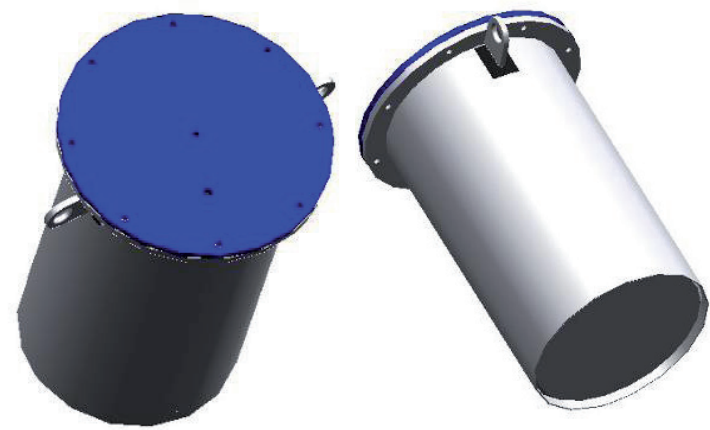

Fig. 14: Model of test container.

\section{Conclusion}

For certification of containers for transport of spent nuclear fuel is necessary to realize analysis that confirm fulfillment of demands of Regulation ÚJD SR No.57/2006 Z.z.. For verification of demands in the meaning of above-mentioned regulation can be used analytical, numerical or experimental methods.

In the paper is given methodology for experiments that should ensure certification of container in accordance to given regulations and that will ensure safety of container. The experiments should

[6] ASTM E 837-01 Standard Test Method for Determining Residual Stresses by the Hole Drilling Strain-Gage Method. New York, 2001.

[7] Trebuňa, F., Šimčák, F., 2007: Príručka experimentálnej mechaniky, 1. vydanie - Košice: SjF TU, 2007, 1526 s., ISBN 970-80-8073-816-7.

[8] Trebuňa, F., Šarga, P., 2011d: Using of program MEZVYNA for Measurement of residual Stresses to Solving Practical Problems. Acta Mechanica Slovaca, Vol. 15, No. 2, 2011, pp. 14-20, ISSN 1335-2393.

[9] Múller, K., Melnik, N., Quercetti, T., Droste, B., 2007: Impact target characterization of the BAM drop test facility. 15th Int. Symposium - PATRAM 2007, Miami, Florida, USA, october 21-26, 2007.

[10] Wille, F., Ballheimer, V., Droste, B., 2007: Suggestons for correct performance of IAEA $1 \mathrm{~m}$ puncture bar drop test with reduced - scale packages cousidering similarity thcory aspects. 15th Int. Symposium - PATRAM 2007, Miami, Florida, USA, october 21-26, 2007.

[11] Trebuňa, F. et al. 2008: Výpočtové overenie kontajnera C30 typu B(u) v súlade s vyhláškou ÚJD SR č. 57/2006 Z.z (§ 7). 


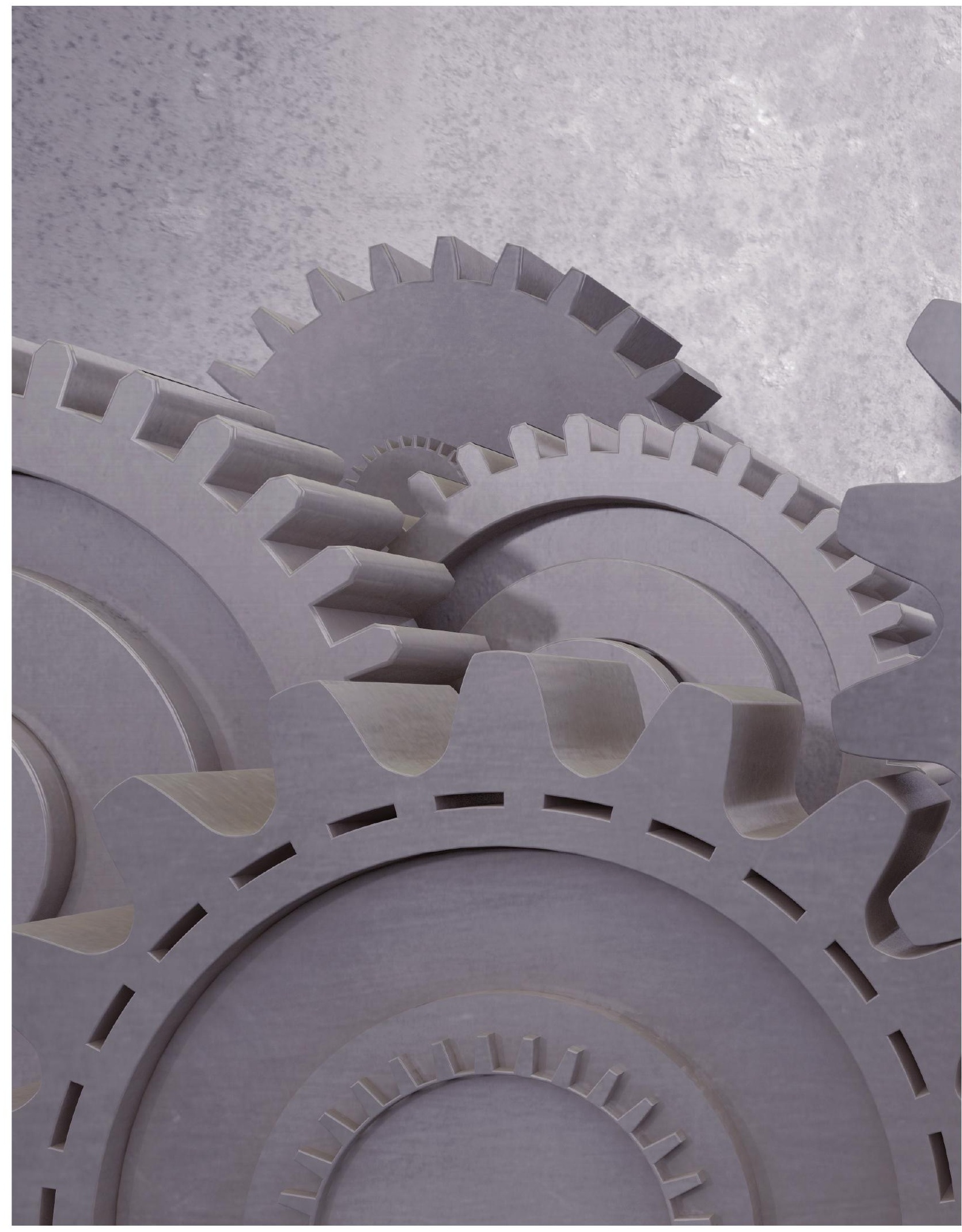




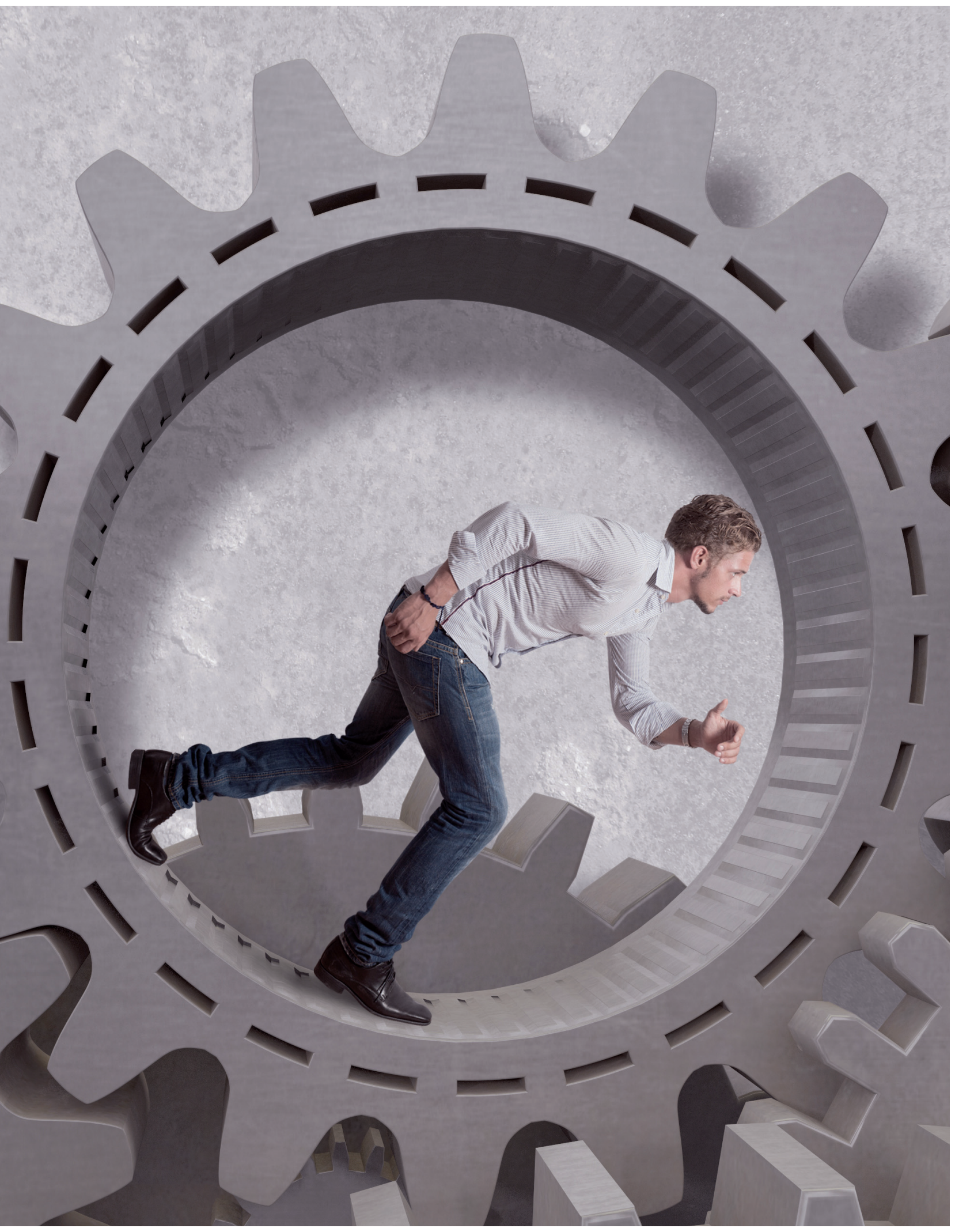

